\begin{tabular}{|c|c|c|c|c|c|}
\hline ISRA (India) & $=3.117$ & SIS (USA) & $=0.912$ & ICV (Poland) & $=6.630$ \\
\hline ISI (Dubai, U. & $=0.829$ & РИНЦ (Russia) & $=0.156$ & PIF (India) & $=1.940$ \\
\hline GIF (Australia) & $=0.564$ & ESJI (KZ) & $=8.716$ & IBI (India) & $=4.260$ \\
\hline JIF & $=1.500$ & SJIF (Morocco) & $=5.667$ & OAJI (USA) & $=0.350$ \\
\hline
\end{tabular}

\section{SOI: 1.1/TAS DOI: 10.15863/TAS International Scientific Journal Theoretical \& Applied Science}

p-ISSN: 2308-4944 (print) e-ISSN: 2409-0085 (online)

Year: $2019 \quad$ Issue: $04 \quad$ Volume: 72

Published: $30.04 .2019 \quad$ http://T-Science.org
QR - Issue

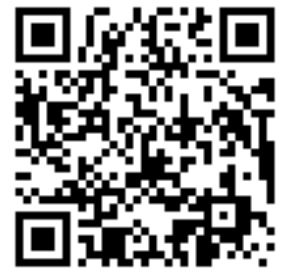

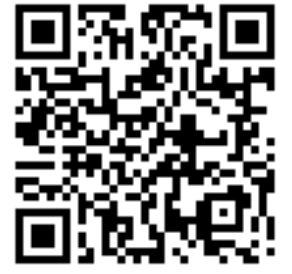

Zulfiya Muxiddinovna Maxmudova teacher

Tashkent State Technical University named after Islam Karimov

Xurmatoy Sobirjanovna Valiyeva

teacher

Tashkent State Technical University named after Islam Karimov

\title{
METHODS OF LEARNING ENGLISH IN THE TECHNICAL UNIVERSITY
}

\author{
Abstract: An important role in the modern technical University is the study of English. This article provides a \\ brief overview of the methods used in vocational training and their analysis. \\ Key words: English, methodology, multilevel training; continuous training; complex method; perception of \\ information; thematic communication. \\ Language: English \\ Citation: Maxmudova, Z. M., \& Valiyeva, X. S. (2019). Methods of learning English in the technical university. \\ ISJ Theoretical \& Applied Science, 04 (72), 463-466. \\ Soi: http://s-o-i.org/1.1/TAS-04-72-58 Doi: crossef https://dx.doi.org/10.15863/TAS.2019.04.72.58
}

\section{Introduction.}

Today, the reform of the education system is one of the most pressing issues. On the whole, first period of independence to the present day reform education system and prepared high ability specialist as one of the most important priorities of the state policy attention. Currently, much actualize area the problem of linguistic knowledge. The amount of professional information in foreign languages is huge and continues to grow. The most dynamic in terms of international integration and exchange of information are the sectors of the economy, law, industry, supply and trade and market relations and aviation, the rapid development of which leads to the need for foreign language proficiency of each industry specialist [1]

Classical approaches of teaching a foreign language, previously used as independent methods, are somewhat losing their effectiveness in modern times. Due to the increasing information load, it is difficult for students to assimilate the material, the culture of education is also changing, methods of presenting language knowledge and monitoring individual progress are being improved. Very popular methods of studying ESP - methods of learning a professionally-oriented language or language for special purposes, as evidenced by the published monographs [2], the development of methods of teaching ESP, conducted research.

Development of programs and curricula for training students to teach technical English at the University

According to the program recommended by the scientific and methodological Council for foreign languages can be noted the main provisions fixed in the documents prescribing the modernization of higher education:

- Foreign language proficiency is an integral part of the professional training of all specialists at the University.

- The English language course is multi-level and is developed in the context of continuing education.

- English language learning is based on an interdisciplinary, integrated framework.

- English language training is aimed at the comprehensive development of communicative, cognitive, informational, socio-cultural, professional and General cultural competences of students.

But, even with a single program, you must always take into account the specifics of the institution or its departments, the needs of customers and students themselves. One of the main factors in language learning is the teachers themselves. The development of curricula should take into account the 


\begin{tabular}{|c|c|c|c|c|c|c|}
\hline \multirow{4}{*}{ Impact Factor: } & ISRA (India) & $=3.117$ & SIS (USA) & $=0.912$ & ICV (Poland) & $=6.630$ \\
\hline & ISI (Dubai, UAE & $=0.829$ & РИНЦ (Russia & $=0.156$ & PIF (India) & $=1.940$ \\
\hline & GIF (Australia) & $=0.564$ & ESJI (KZ) & $=8.716$ & IBI (India) & $=4.260$ \\
\hline & JIF & $=1.500$ & SJIF (Morocco & $=5.667$ & OAJI (USA) & $=0.350$ \\
\hline
\end{tabular}

variety of methods and approaches used, depending on the purpose of the course and available resources.

The diagram shows the main methods used and applied in the study of the English language:

- Grammar translation method;

- Direct study;

- Audio-lingualism;

- Suggestopedia method;

- "Silent" method (silence method);

- Community (group) learning method);

- Communicative method;

- Fundamental Eclecticism.

Information and communication technologies (ICT) are also the most widely used methods at present.

Based on this, we can distinguish four groups of methods: problem learning, Autonomous education, learning abstraction, learning using ICT.

Traditionally, methods of direct language learning are used together with the method of grammatical translation. Listening and image visualization are widely used. [3]

Suggestopedia method based on the study of language under stress in a calm and relaxing atmosphere difficult to apply in Universities due to the nature of the learning process. In a certain number of educational institutions that have entered into close integration with foreign teachers, a "quiet" method is used, i.e. a method of non-verbal education, consisting in the fact that the desire to know the language is initially inherent in the person who wants to learn it, and most importantly - do not interfere with students and do not impose the Following this method, the teacher initially does not say anything, using graphic illustrations, tables and other didactic materials. The method shows its effectiveness, but its use in a technical school is difficult.

The next most popular method is community learning (group), which consists in motivating the internal work of a group of students studying English through the collective resolution of a number of tasks. The method demonstrates pedagogical efficiency and its application in teaching technical English.

Communicative method is widely used in highquality training of professional staff, based on dialogue and conversational communication with native speakers.

The principal Eclecticism, the method of selective combination of the most effective modern methods, deducing the goals and objectives of training, based on the needs and interests of the student, unfortunately, is still exotic, because of the complexity of its implementation. Nevertheless, this method allows you to fully learn the language, using a variety of approaches to the submission of information and realizing the potential of the student. Briefly, the difference in these methods can be presented in the form of the following table:

Table 1. Summary table of methods

\begin{tabular}{|c|c|c|}
\hline Method & Direction & Characteristic \\
\hline $\begin{array}{l}\text { Grammatical translation } \\
\text { method }\end{array}$ & Printed / written literary texts & Translation from English into native language \\
\hline Direct study & $\begin{array}{c}\text { Daily language practice, } \\
\text { speaking the target language, } \\
\text { using it as a " second native } \\
\text { language» }\end{array}$ & $\begin{array}{l}\text { Learning by linking meanings and images } \\
\text { directly in the target language }\end{array}$ \\
\hline Audio-lingualism & Speech and sound models & $\begin{array}{c}\text { Listening and speaking exercises, coupled with } \\
\text { the basic practice of writing only in the target } \\
\text { language }\end{array}$ \\
\hline Cognitive techniques & The rules of grammar & $\begin{array}{l}\text { Acquisition and reproduction of grammatical } \\
\text { rules of the studied language in the context of } \\
\text { understanding and perception }\end{array}$ \\
\hline $\begin{array}{l}\text { "Silent" method (silence } \\
\text { method) }\end{array}$ & $\begin{array}{l}\text { Student faster action of the } \\
\text { teacher }\end{array}$ & $\begin{array}{l}\text { The teacher is silent to students inquired about } \\
\text { how" works " English }\end{array}$ \\
\hline Suggestopedic method & $\begin{array}{l}\text { The ambiguity of the texts and } \\
\text { the extensive thesaurus }\end{array}$ & $\begin{array}{l}\text { Pleasant atmosphere, with music, encourages } \\
\text { subconscious learning of English }\end{array}$ \\
\hline $\begin{array}{l}\text { Community (group) learning } \\
\text { method) }\end{array}$ & The interaction of the students & $\begin{array}{l}\text { Understanding of English through active } \\
\text { interaction of students }\end{array}$ \\
\hline Communicative method & $\begin{array}{l}\text { Interaction, strengthening of } \\
\text { interpersonal relations and } \\
\text { conducting semantic } \\
\text { negotiations }\end{array}$ & $\begin{array}{l}\text { Understanding of the English language through } \\
\text { active interaction of the student; role-playing } \\
\text { games, games, information gaps }\end{array}$ \\
\hline
\end{tabular}




\begin{tabular}{|c|c|c|c|c|c|c|}
\hline \multirow{4}{*}{ Impact Factor: } & ISRA (India) & $=3.117$ & SIS (USA) & $=0.912$ & ICV (Poland) & $=6.630$ \\
\hline & ISI (Dubai, UAE & $=0.829$ & РИНЦ (Russia) & $=0.156$ & PIF (India) & $=1.940$ \\
\hline & GIF (Australia) & $=0.564$ & ESJI (KZ) & $=8.716$ & IBI (India) & $=4.260$ \\
\hline & JIF & $=1.500$ & SJIF (Morocco) & ) $=5.667$ & OAJI (USA) & $=0.350$ \\
\hline
\end{tabular}

\begin{tabular}{|c|c|c|}
\hline Natural method & Audition & $\begin{array}{c}\text { English speech does not reach students until } \\
\text { they are prepared; meaning is clarified through } \\
\text { actions and visual effects }\end{array}$ \\
\hline $\begin{array}{c}\text { Content-based, task-based, and } \\
\text { participatory methods }\end{array}$ & $\begin{array}{c}\text { Anything that is not a } \\
\text { communicative way of } \\
\text { information transmission, not } \\
\text { the structure of the English } \\
\text { language }\end{array}$ & $\begin{array}{c}\text { content is based on students ' attitude to life: } \\
\text { topics, tasks, problem solving }\end{array}$ \\
\hline $\begin{array}{c}\text { Prepared learning strategy, co- } \\
\text { learning and multiple thinking }\end{array}$ & How to learn & $\begin{array}{c}\text { the Strategy of learning, mutual cooperation. } \\
\text { Activities vary according to different levels }\end{array}$ \\
\hline
\end{tabular}

The seemingly simple procedure for determining the content of training and organization of training should include theoretical provisions. The curriculum should therefore be adjusted to the overall methodology of the course.

The use of innovative methods and synthesis of the optimal approach to language learning in a technical University

In modern times, a variety of interactive, automated methods are widely used:

- Multimedia;

- Online communication with the teacher;

- Thematic communication in the target language in various social networks, forums;

- Video tutorials, listening;

- Electronic communication: e-mail, conference, etc.

The use of interactive/media/electronic AIDS in language learning can be characterized as a combination of natural, cognitive and contentoriented methods using audio-lingualism. This combination significantly increases the efficiency of language learning, using a set of advantages of the methods used, but nevertheless, the use of information technology in the study of English in technical Universities is not widespread so widely because of the unreasonableness of the over complication of the course. The most optimal statistical processing of data on students' progress shows itself the integration of the method of grammatical translation, coupled with the use of thematic content in group study and active communication of students in the classroom. [4]

Today, the ability to use the means of computing and telecommunications in their subject area should be considered as a criterion of general literacy, comparable to today with the traditional interpretation of this concept - as the ability to read, write and count.

So, What are the most frequently used elements of the use of information and computer technologies in educational process:

- electronic textbooks and manuals, displayed via a computer,

- Multimedia projector,

- Interactive whiteboards, books,

- Electronic encyclopedias and reference
- Simulators and testing programs,

- Educational resources of the Internet,

- DVD and CD discs with pictures and illustrations,

- Video and audio equipment,

- Interactive maps and atlases,

- Interactive conferences and competitions,

- Materials for distance learning,

- Research projects and projects.

- distance learning.

Learn English using and Using Information and computer technology gives children the opportunity to participate in the test, quizzes, competitions, contests, conducted over the Internet, chat with peers from other countries, participate in chat rooms, video conferencing, etc. Students can receive any information on the problem they are working on, namely: linguistic and regional material, news from the life of famous people, articles from newspapers and magazines, necessary Reference, etc. Classical and integrated lessons, accompanied by multimedia presentations, on-line tests and software products, allow my students to deepen the knowledge they received earlier, as the English proverb says: "I heard and forgot, I saw and remembered.[5]"

\section{Conclusion.}

The approaches to the organization of the educational process in the study of English in a technical University have shown their applicability and effectiveness, which is confirmed by an increase in students ' interest in language learning and improvement of academic performance on the basis of surveys and statistical analysis. The modification of ESP - methods should take into account the industry focus and relevant didactic materials[6]. The Resource-didactic base of the Department should be regularly modernized, due to the rapid development of technical and material resources and the expansion of the semantic structure of the language base. When preparing students it is very important to assess the initial level of language understanding of the student and his individual characteristics. This approach is applicable in the study of any foreign language in any industry, but it shows the greatest efficiency when used in technical specialties. The main methods used 


\begin{tabular}{|c|c|c|c|c|c|c|}
\hline \multirow{4}{*}{ Impact Factor: } & ISRA (India) & $=3.117$ & SIS (USA) & $=0.912$ & ICV (Poland) & $=6.630$ \\
\hline & ISI (Dubai, UAE & $=0.829$ & РИНЦ (Russia & $=0.156$ & PIF (India) & $=1.940$ \\
\hline & GIF (Australia) & $=0.564$ & ESJI (KZ) & $=8.716$ & IBI (India) & $=4.260$ \\
\hline & JIF & $=1.500$ & SJIF (Morocco & $=\mathbf{5 . 6 6 7}$ & OAJI (USA) & $=0.350$ \\
\hline
\end{tabular}

in the implementation of this approach are considered, psychological and psychophysiological features of perception and memorization of information are briefly described. The technique of presentation of material and interaction with students is deduced.

\section{References:}

1. (2008). e-library. Retrieved 2019, from www.eBookstore.tandf.co.uk

2. Dudley-Evans, T. (1998). Developments in English for Specific Purposes. Cambridge University Press.

3. Hutchinson, T. (1987). English for Specific Purposes. Cambridge University Press.

4. Farkhodzhonova, N. F. (2016). Problemy primeneniya innovatsionnykh tekhnologiy $v$ obrazovatel"nom protsesse na mezhdunarodnom urovne. Innovatsionnye tendentsii, sotsial'noekonomicheskie i pravovye problemy vzaimodeystviya $\mathrm{v}$ mezhdunarodnom prostranstve. pp. 58-61.

5. Minaeva, L. V., et al. (1997). Prepodavanie angliyskogo yazyka dlya spetsial'nykh tseley: teoriya i praktika. Mosk. gos. un-t im. M.V. Lomonosova, In-t gos. upr. i sots. issled. Moscow: Univ. gumanitar. Litsey.
6. (2012). Teaching ESP: Best Practices / IBM PC CD - ROM: Published by "REPETITOR MultiMedia" for The English Language Office of the U.S. Embassy. Moscow.

7. Carsten B. (2013). Language in aviation: The relevance of linguistics and relevance theory, LSP Journal, Vol.4, No.1. http://lsp.cbs.dk

8. (2017). Sovremennye metodiki izucheniya angliyskogo yazyka vzroslymi. Retrieved January 24, 2019, from http://allstuds.ru/stattipo-angliyskomu-yaziku/2090-metodikiprepodavanija-angliyskogo-jazyka-vzroslimi

9. (2008). Oxford English for Aviation / IBM PC CD-ROM: published by "Oxford University Press" - England.

10. (2011). Cambridge University Press, ISBN: 9780521173787, Cambridge IELTS.

11. Tatyana, T. (2017). ELTFamily. Retrieved January 24, 2019, from http://englishwell.biz/modals-in-english.html 